Perbandingan pengaruh latihan ladder drills in out dan ickey shuffle terhadap kecepatan dan kelincahan

\title{
The comparison of the effect of ladder drills in out training and ladder drills ickey shuffle exercises on increasing speed and agility
}

\author{
Faried Fatchurrahman ${ }^{1}$, Andun Sudijandoko ${ }^{2}$, Achmad Widodo $^{3}$ \\ ${ }^{1,2,3}$ Department of Sports Science, Universitas Negeri Surabaya, Jl. Ketintang, Surabaya, \\ 60231, Indonesia
}

Received: 25 February 2019; Revised: 31 March 2019; Accepted: 2 May 2019

https://doi.org/10.29407/is unpgri.v5i1.12753

\begin{abstract}
Abstrak
Penelitian ini bertujuan untuk menganalisis perbandingan pengaruh latihan ladder drills in out dan latihan ladder drills ickey shuffle terhadap peningkatan kecepatan dan kelincahan pada siswa ekstrakurikuler futsal SMA Negeri 1 Krian. Metode yang digunakan dalam penelitian ini adalah metode deskriptif kuantitatif dengan metode eksperimen semu. Populasi dalam penelitian ini adalah seluruh siswa yang mengikuti ekstrakurikuler futsal SMA Negeri 1 Krian sebanyak 30 siswa. Rancangan penelitian ini menggunakan matching only design dengan analisis data menggunakan ANOVA. Hasil penelitian menunjukkan bahwa latihan ladder drills in out berpengaruh secara signifikan terhadap peningkatan kecepatan dan kelincahan dan latihan ladder drills ickey shuffle berpengaruh secara signifikan terhadap peningkatan kecepatan dan kelincahan. Kesimpulan pada penelitian ini adalah latihan ladder drill in out dan ickey shuffle berpengaruh secara signifikan terhadap kecepatan dan kelincahan.
\end{abstract}

Kata kunci: ladder drills in out, ickey shuffle, kecepatan, kelincahan.

\begin{abstract}
The purpose of this study was to analyze the comparison of the effect of ladder drills in out training and ladder drills ickey shuffle exercises on increasing speed and agility in students of futsal extracurricular activities at SMA 1 Krian. The method used in this research is quantitative descriptive method with a quasiexperimental method. The population in this study were all students who participated in futsal extracurricular activities of SMAN 1 Krian with the number of the subject of 30 students. The design of this study uses only matching design with data analysis using ANOVA. The results showed that the ladder drills in out exercise significantly affected the increase in speed and agility and the ladder drills ickey shuffle exercise had a significant effect on increasing speed and agility. The conclusion of this study was that the ladder drill in out and the ickey shuffle significantly influence speed and agility.
\end{abstract}

Keywords: ladder drills in out, ickey shuffle, speed, agility.

\section{PENDAHULUAN}

Olahraga adalah aktivitas yang mempunyai pengaruh terhadap kehidupan sehari-hari manusia. Gerak dalam aktivitas olahraga adalah 
gerak yang memiliki tujuan. Mylsidayu \& Kurniawan (2015) menyebutkan ada 4 dasar yang menjadi tujuan manusia berolahraga antara lain sebagai berikut : 1), Olahraga yang bertujuan untuk rekreasi, artinya dilakukan untuk mengisi waktu senggang dan sifatnya menyenangkan 2), Olahraga yang bertujuan untuk pendidikan, artinya dilakukan dengan tujuan yang telah tertera pada kurikulum dan silabus 3), Olahraga yang bertujuan untuk kesegaran jasmani, artinya dilakukan dengan tujuan tertentu dan di bawah asuhan atau arahan tenaga profesional 4), Olahraga yang bertujuan untuk prestasi, artinya dilakukan dengan persiapan yang matang dan program latihan yang sistematis, progresif, dilakukan berulang-ulang dan disiplin ilmu terkait. Olahraga yang perkembangannya cukup menarik perhatian masyarakat beberapa tahun ini salah satunya adalah olahraga futsal. Terbukti dengan besarnya antusias masyarakat melalui kejuaraan nasional seperti Specs Futsalogy, Pocari Sweat Futsal Championship, Hydro Coco Cup National, LIMA (Liga Mahasiswa), LIFUMA dan Liga Nusantara (LINUS) mulai dari tingkat SMP, SMA dan Mahasiswa laki-laki maupun wanita serta untuk tujuan rekreasi atau prestasi. Tujuan utama mempersiapkan fisik dalam latihan adalah untuk meningkatkan potensi fungsional atlet dan mengembangkan kemampuan biomotorik ke standar yang paling tinggi. Tanpa persiapan kondisi fisik yang memadai maka atlet khususnya atlet pemula akan kesulitan untuk mengembangkan teknik, taktik dan juga strategi dalam kegiatan olahraga. Latihan merupakan proses eksekusi berulang, latihan progresif atau pekerjaan yang meningkatkan potensi untuk mencapai kinerja yang optimal (Bompa \& Haff, 2009).

Olahraga futsal memiliki karakteristik sendiri yakni pergerakan kaki dinamis, maka komponen yang domain harus dimiliki pemain futsal yakni daya tahan (endurance), kekuatan (strength), kecepatan (speed), kelincahan (agility), daya ledak (power), dan tentunya tanpa meninggalkan komponen biomotor yang lainnya (Mathisen, 2014).

Latihan tangga atau ladder drill merupakan cara terbaik untuk meningkatkan kecepatan dan kelincahan, kordinasi dan kecepatan secara 
Faried Fatchurrahman, Andun Sudijandoko, dan Achmad Widodo

Perbandingan pengaruh latihan ladder drills in out dan ickey shuffle terhadap kecepatan dan kelincahan

keseluruhan, dan latihan ini tidak dimaksudkan untuk mengalami kelelahan berarti atau mengalami sesak nafas (Rajendran, 2016). Sedangkan ladder drill adalah suatu bentuk latihan untuk meningkatkan kelincahan, kecepatan, koordinasi, dan kaki secara keseluruhan (Anderson, 2019). Latihan ladder drill dengan menggunakan sebuah alat fitnes berupa tangga dimana nantinya atlet berlari, meloncat dan melompat dengan pergerakan kaki dengan cepat melewati tangga sehingga dapat membanu mengembangkan kelincahan dan kecepatan (speed).

Penelitian tentang ladder drill telah banyak dilakukan, namun perlu diketahui jenis latihan ladder drill sangat bervariasi. Penelitian terbaru menunjukkan bahwa latihan ladder drill dapat menigkatkan kecepatan dan kelincahan (Sethu, 2014). Yudasakti (2017) dalam risetnya menyimpulkan bahwa 12 minggu latihan ladder drill icky shuffle mampu meningkatkan kecepatan. Puriana (2017) dalam risetnya menyimpulkan ladder drill hop scotch pattern dapat meningkatkan kelincahan. Fantiro (2018) menerapkan latihan ladder drill speed run dan ladder drill crossover terhadap peningkatan kelincahan (agility). Berdasarkan riset terdahulu, penulis termotivasi untuk menerapkan latihan ladder drill. Penulis menggunakan latihan ladder drills in out dan ickey shuffle dalam meningkatkan kecepatan dan kelincahan. Hal ini yang membedakan penelitian ini berbeda dengan penelitian sebelumnya. Penulis sekaligus menggunakan 2 variabel untuk ditingkatkan, yakni kecepatan dan kelincahan.

Beberapa tahun belakangan ini, olahraga futsal sudah mulai dilakukan pada kegiatan ekstrakulikuler sekolah baik itu tingkat dasar, tingkat menengah dan tingkat akhir. Di Jawa Timur, khususnya Kabupaten Sidoarjo hampir setiap tahun menyelenggarakan turnamen futsal tingkat SMA (Sekolah Menengah Atas) yang diikuti berbagai sekolah. SMA Negeri 1 Krian adalah salah satu tim peserta turnamen futsal yang secara rutin mengikuti turnamen futsal di Kabupaten Sidoarjo dan Kota sekitarnya. Dari hasil beberapa turnamen yang diikuti, tim futsal SMAN 1 
Krian mengalami penurunan prestasi. Setelah penulis beserta pelatih melakukan evaluasi terhadap performance pemain, menunjukkan profil pemain untuk kecepatan dan kelincahan adalah sebagai berikut: kecepatan dengan kategori "sangat bagus " sebanyak 1 pemain $(3,33 \%)$, kategori "bagus" 2 pemain (6,66\%), kategori "cukup" 4 pemain $(13,3 \%)$, kategori "jelek" 10 pemain (33,3\%), kategori sangat jelek 13 pemain $(43,3 \%)$. Kelincahan dengan kategori "sangat bagus" 0 pemain $(0 \%)$, kategori "bagus" sebanyak 2 pemain (6,66\%), kategori "cukup" sebanyak 15 pemain (50\%), kategori "sangat jelek" 13 pemain $(43,3 \%)$.

Berdasarkan hasil pengamatan penulis di ekstrakurikuler futsal SMA Negeri 1 Krian, bahwa dalam setiap sesi latihan hanya menerapkan latihan teknik dengan menggunakan drill-drill yang mengarah ke skill dasar permainan futsal. Sementara bentuk latihan fisik untuk meningkatkan komponen biomotorik futsal yang menunjang kinerja skill seperti kelincahan dan kecepatan jarang sekali diberikan, sehingga para siswa yang mengikuti ekstrakurikuler futsal di SMA Negeri 1 Krian terkendala pada kemampuan fisiknya yang seharusnya hal itu membantu memaksimalkan kinerja skill dalam bermain dan prestasi mereka.

Penulis berupaya meningkatkan aspek kecepatan dan kelincahan, sebab keduanya merupakan komponen kondisi fisik yang sangat penting dalam permainan futsal. Kontribusi kelincahan dan kecepatan dapat memperbaiki teknik dribbling (Purnomo, 2018). Tujuan dari penelitian ini menganalisis perbedaan pengaruh latihan ladder drill in out dan ickey shuffle terhadap kecepatan dan kelincahan. Sehingga berdasarkan hasil penelitian ini diharapkan memberikan kontribusi yang signifikan terhadap pelatih futsal dalam memberikan variasi-variasi bentuk latihan yang dapat meningkatkan komponen kelincahan dan kecepatan pemain sehingga menunjang kemampuanya dalam bermain futsal.

\section{METODE}

Penelitian ini menggunakan jenis penelitian eksperimen semu (quasexperiment) dengan pendekatan kuantitatif. Rancangan penelitian ini 
menggunakan matching-only design. Populasi pada penelitian ini adalah keseluruhan dari siswa yang mengikuti ekstrakurikuler futsal SMA Negeri 1 Krian yang berlokasi di Jalan Gub. Soenandar Prijosoedarmo, Kecamatan Krian, Kabupaten Sidoarjo yang berjumlah 30 siswa. Instrumen tes yang digunakan untuk mengukur kecepatan adalah lari sprint 30 meter dan untuk mengukur kelincahan menggunakan agility $T$ test. Analisis data menggunakan teknik statistik deskriptif dan dianalisis dengan bantuan program komputer SPSS (Statistical Program For Social Science) 20.0.

\section{HASIL DAN PEMBAHASAN}

Hasil

Hasil penelitian hasil tes kecepatan dan kelincahan yang dilakukan mulai dari tes awal atau pretest tanpa diberi perlakuan sebelumya, lalu yang kedua yaitu tes akhir atau posttest yang diberi perlakuan sebelum tes. Adapun data penelitian ini menggunakan 30 sampel siswa dari SMAN 1 Krian yang mengikuti kegiatan ekstrakurikuler futsal.

Sebelum menguji hipotesis perlu dilakukan uji normalitas data yang bertujuan untuk memastikan bahwa data yang diperoleh berdistribusi normal. Uji normalitas pada penelitian ini menggunakan metode Kolmogorov-Smirnov dapat dilihat pada tabel 1 berikut.

Tabel 1. Hasil Uji Normalitas Keseluruhan Kelompok

\begin{tabular}{lcccccc}
\hline \multicolumn{1}{c}{ Variabel } & Tahap & $\begin{array}{c}\text { Kel. } \\
\text { Box } \\
\text { Jump }\end{array}$ & $\begin{array}{c}\text { Kel. } \\
\text { Burpee }\end{array}$ & $\begin{array}{c}\text { Kel. } \\
\text { Tuck } \\
\text { Jump }\end{array}$ & $\begin{array}{c}\text { Kel. } \\
\text { Kontrol }\end{array}$ & Keterangan \\
\hline $\begin{array}{l}\text { Power. } \\
\begin{array}{l}\text { Otot. } \\
\text { Tungkai. }\end{array}\end{array}$ & PreTest & 0.699. & 0.995. & 0.680. & 0.847. & Normal \\
\cline { 2 - 7 } & PostTest & 0.945 & 0.950 & 0.791 & 0.815 & Normal \\
\hline \multirow{2}{*}{ Kecepatan } & PreTest & 0.748 & 0.970 & 0.852 & 0.906 & Normal \\
\cline { 2 - 7 } & PostTest & 0.896 & 0.978 & 0.909 & 0.910 & Normal \\
\hline
\end{tabular}

Hasil uji normalitas berdasarkan pada tabel 1 menunjukkan bahwa data berdistribusi normal. Selanjutnya dilakukan uji homogenitas yang 
Faried Fatchurrahman, Andun Sudijandoko, dan Achmad Widodo

Perbandingan pengaruh latihan ladder drills in out dan ickey shuffle terhadap kecepatan dan kelincahan

bertujuan untuk memastikan bahwa varian dari setiap kelompok sama atau sejenis. Hasil uji homogenitas dapat dilihat pada tabel 2 berikut.

Tabel 2. Hasil Uji Homogenitas Seluruh Kelompok

\begin{tabular}{ccccc}
\hline No & Data & Asymp. Sig & a & Keterangan \\
\hline 1 & Pre-Post Sprint & 0.173 & 0.05 & Homogen \\
\hline 2 & Pre-Post Agility & 0.862 & 0.05 & Homogen \\
\hline
\end{tabular}

Berdasarkan hasil perhitungan uji homogenitas yang ditunjukkan pada tabel 2 dapat disimpulkan bahwa nilai signifikasi pada tes sprint dan tes agility menunjukkan nilai Sig. $>0,05$. Sehingga dapat disimpulkan bahwa varian populasi adalah sama (homogen).

Hasil data pretest dan posttest keseluruhan sampel baik dari kelompok kontrol maupun kelompok eksperimen menggunaan tes yaitu tes sprint 30 meter untuk kecepatan dan agility $t$-test untuk kelincahan dapat ditunjukkan pada tabel 3 berikut:

Tabel 3 Uji ANOVA

\begin{tabular}{|c|c|c|c|c|c|c|}
\hline & & $\begin{array}{l}\text { Sum of } \\
\text { Squares }\end{array}$ & $d f$ & $\begin{array}{l}\text { Mean } \\
\text { Square }\end{array}$ & $\boldsymbol{F}$ & Sig. \\
\hline \multirow{3}{*}{$\begin{array}{l}\text { LDIO Sprint } \\
\text { Hom }\end{array}$} & Between Groups & 1.196 & 1 & 1.196 & 14.101 & .001 \\
\hline & Within Groups & 1.526 & 18 & .085 & & \\
\hline & Total & 2.722 & 19 & & & \\
\hline \multirow{3}{*}{$\begin{array}{l}\text { LDIO agility } \\
\text { Hom }\end{array}$} & Between Groups & 7.357 & 1 & 7.357 & 5.450 & .031 \\
\hline & Within Groups & 24.296 & 18 & 1.350 & & \\
\hline & Total & 31.652 & 19 & & & \\
\hline \multirow{3}{*}{$\begin{array}{l}\text { LDIS sprint } \\
\text { Hom }\end{array}$} & Between Groups & .929 & 1 & .929 & 7.346 & .014 \\
\hline & Within Groups & 2.276 & 18 & .126 & & \\
\hline & Total & 3.205 & 19 & & & \\
\hline \multirow{3}{*}{$\begin{array}{l}\text { LDIS agility } \\
\text { Hom }\end{array}$} & Between Groups & 5.450 & 1 & 5.450 & 12.195 & .003 \\
\hline & Within Groups & 8.044 & 18 & .447 & & \\
\hline & Total & 13.494 & 19 & & & \\
\hline \multirow{3}{*}{$\begin{array}{l}\text { KON sprint } \\
\text { Hom }\end{array}$} & Between Groups & .959 & 1 & .959 & 6.707 & .018 \\
\hline & Within Groups & 2.574 & 18 & .143 & & \\
\hline & Total & 3.534 & 19 & & & \\
\hline \multirow{3}{*}{$\begin{array}{l}\text { KON agility } \\
\text { Hom }\end{array}$} & Between Groups & .538 & 1 & .538 & 1.801 & .196 \\
\hline & Within Groups & 5.377 & 18 & .299 & & \\
\hline & Total & 5.915 & 19 & & & \\
\hline
\end{tabular}


Kemudian hasil tabulasi data tersebut diolah dan dianalisis untuk menguji hipotesis yang sudah dajukan sebelumnya.

1. Uji Beda Paired Sample t Test (Pretest dan Posttest)

Nilai yang digunakan dalam menghitung uji paired $t$ test adalah nilai dari hasil pretest dan posttest perlakuan yaitu ladder drill in out dan ladder drill ickey shuffle.

Tabel 4. Uji Beda Paired Sampel t-Test Pretest Seluruh Kelompok

\begin{tabular}{ccccccc}
\hline No & Variabel & Mean & $\begin{array}{c}\text { Std. } \\
\text { Deviasi }\end{array}$ & $\mathbf{T}$ & $\boldsymbol{d f}$ & $\begin{array}{c}\text { Sig. (2- } \\
\text { tailed) }\end{array}$ \\
\hline 1 & Kecepatan & 0.453 & 0.211 & 11.737 & 29 & 0.000 \\
\hline 2 & Kelincahan & 0.862 & 0.725 & 6.506 & 29 & 0.000 \\
\hline
\end{tabular}

Berdasarkan tabel 4 dapat diketahui bahwa nilai sig. (2-tailed) pada variabel kecepatan sebesar $0,000<0,05$, artinya ada perbedaan yang signifikan antara pretest dan posttest.

Table 5.Uji Beda Paired Sampel t-Test Posttest Kelompok Ladder Drill in Out

\begin{tabular}{ccccccc}
\hline No & Variabel & Mean & $\begin{array}{c}\text { Std. } \\
\text { Deviasi }\end{array}$ & $\mathbf{T}$ & $\boldsymbol{d f}$ & $\begin{array}{c}\text { Sig. (2- } \\
\text { tailed) }\end{array}$ \\
\hline 1 & Kecepatan & 0.489 & 0.184 & 8.388 & 9 & 0.000 \\
\hline 2 & Kelincahan & 1.213 & 0.458 & 8.369 & 9 & 0.000 \\
\hline
\end{tabular}

Berdasarkan tabel 5 dapat diketahui bahwa nilai sig. (2-tailed) pada variabel kecepatan sebesar $0,000<0.05$, artinya ada pengaruh latihan ladder drill in out terhadap peningkatan kecepatan. Dan nilai sig. (2-tailed) pada variabel kelincahan sebesar $0,000<0.05$, artinya ada pengaruh latihan ladder drill in out terhadap peningkatan kelincahan. 
Faried Fatchurrahman, Andun Sudijandoko, dan Achmad Widodo

Perbandingan pengaruh latihan ladder drills in out dan ickey shuffle terhadap kecepatan dan kelincahan

Tabel 6. Uji Beda Paired Sampel t Test Posttest Kelompok Ladder drill Ickey Shuffle

\begin{tabular}{ccccccc}
\hline No & Variabel & Mean & $\begin{array}{c}\text { Std. } \\
\text { Deviasi }\end{array}$ & $\mathbf{T}$ & $\boldsymbol{d f}$ & $\begin{array}{c}\text { Sig. (2- } \\
\text { tailed) }\end{array}$ \\
\hline 1 & Kecepatan & 0.431 & 0.234 & 5.826 & 9 & 0.000 \\
\hline 2 & Kelincahan & 1.044 & 0.966 & 3.416 & 9 & 0.008 \\
\hline
\end{tabular}

Berdasarkan tabel 6 dapat diketahui bahwa nilai sig. (2-tailed) pada variabel kecepatan sebesar 0,000 $<0.05$, artinya ada pengaruh latihan ladder drill ickey shuffle terhadap peningkatan kecepatan. Dan nilai sig. (2tailed) pada variabel kelincahan sebesar 0,008 $<0.05$, artinya ada pengaruh latihan ladder drill ickey shuffle terhadap peningkatan kelincahan.

Tabel 7. Uji Beda Paired Sampel t-Test Posttest Kelompok Kontrol

\begin{tabular}{ccccccc}
\hline No & Variabel & Mean & $\begin{array}{c}\text { Std. } \\
\text { Deviasi }\end{array}$ & T & df & $\begin{array}{c}\text { Sig. (2- } \\
\text { tailed) }\end{array}$ \\
\hline 1 & Kecepatan & 0.438 & 0.230 & 6.024 & 9 & 0.000 \\
\hline 2 & Kelincahan & 1.328 & 0.246 & 4.211 & 9 & 0.002 \\
\hline
\end{tabular}

Berdasarkan tabel 7 dapat diketahui nilai sig. (2-tailed) pada variabel kecepatan sebesar $0.000<0.05$, artinya tanpa adanya perlakuan kelompok kontrol juga mengalami peningkatan kecepatan. Dan nilai sig. (2-tailed) pada variabel kelincahan sebesar $0.002<0.05$, artinya tanpa adanya perlakuan kelompok kontrol juga mengalami peningkatan kelincahan.

\section{Pembahasan}

Penelitian ini bertujuan untuk mengetahui pengaruh latihan ladder drills in out dan ickey shuffle terhadap kecepatan dan kelincahan. Latihan ladder drills in out dan ickey shuffle diterapkan pada siswa yang mengikuti ekstrakurikuler futsal SMA Negeri 1 Krian berjumlah 30 siswa. Hasil analisis data menunjukkan bahwa latihan ladder drill ickey shuffle dapat 
meningkatkan kecepatan dan kelincahan siswa yang mengikuti ekstrakurikuler futsal.

Peningkatan tersebut bisa disebabkan oleh beberapa faktor, yang pertama yaitu rutinitas latihan, seperti yang dikatakan McGinnis (2013) bahwa latihan juga dapat dikatakan sebagai sesuatu proses berlatih yang sistematis yang dilakukan secara berulang-ulang yang kian hari jumlah beban latihannya kian bertambah. Faktor lain yang menyebabkan terjadinya peningkatan yaitu jenis latihan.

Ladder adalah peralatan pelatihan yang sangat baik dan berguna untuk meningkatkan kontrol dan kelincahan tubuh serta meningkatkan kecepatan kaki (Rajendran, 2016). Latihan ladder drill adalah bagian penting dari banyak latihan olahraga tim. Mereka membutuhkan atlet untuk menggerakkan kaki mereka dengan cepat dalam gerakan yang tepat dan spesifik (Chandrakumar \& Ramesh, 2015).

Latihan ladder drill adalah suatu pola gerakan memiliki langkahlangkah sebagai berikut: dimulai dari sisi kiri tangga menghadap kesamping, langkahkan kesamping dengan kaki kanan kemudian kiri dan tempatkan didalam kotak (ladder) pertama, langkahkan ayunan langkah seperti awal permulaan ke arah kotak (ladder) dan langkahkan lagi ke luar kotak (ladder) berikutnya hingga yang terakhir. Gerakan ladder drill in out ini mempunyai karakter latihan yang melatih kaki untuk lebih cepat, sehingga latihan ini cukup efisien untuk meningkatkan kecepatan pemain futsal (Chu \& Myer, 2013).

Latihan ladder drill ickey shuffle adalah suatu pola gerakan memiliki langkah-langkah sebagai berikut: latihan ladder drill ickey shuffle adalah suatu pola gerakan mengangkat kaki kedepan dan kesamping menggunakan dua kaki secara bergantian masuk dan satu kaki keluar pada tiap-tiap kotak tangga atau ladder yang berukuran 40 centimeter persegi dan panjang ladder 5 meter dengan berurutan tanpa ada jotak tangga yang terlewatkan. Gerakan ladder drill ickey shuffle ini mempunyai karakter latihan yang melatih kaki, sehingga latihan ini cukup efisien untuk meningkatkan kelincahan pemain futsal. 
Dari hasil tes kelompok kontrol tanpa diberi perlakuan juga mengalami peningkatan yang signifikan, tentang beberapa faktor yang menyebabkan kedua kelompok ini sama-sama mengalami peningkatan dapat dikarenakan saat dilakukan pretest peserta tidak sungguh-sungguh atau dalam keadaan tidak fit, lalu program latihan yang dijalankan oleh pelatih juga sama bagusnya dengan perlakuan yang diberikan kepada kelompok eksperimen. Kelincahan seseorang atlet dalam mengubah gerakan tubuh secara cepat merupakan komponen dasar dalam olahraga tim atau beregu seperti futsal dan sepakbola. Karena selama pertandingan, pemain melakukan gerakan seperti berlari dan mengubah arah gerakan secara cepat, baik dalam menggiring bola maupun menghalangi pergerakan lawan.

Hasil temuan ini sejalan dengan teori tentang latihan ladder drill bahwa bentuk latihan ladder drill dapat meningkatkan kecepatan dan kelincahan (Anderson, 2019; Pramukti \& Junaidi, 2015; Rajendran, 2016; Rinaldi, Jumain, \& Marhadi, 2019; Sethu, 2014). Penelitian terbaru yang dilakukan oleh Tefu (2019) menyimpulkan latihan ladder speed run lebih berpengaruh pada kecepatan dan in out drill lebih berpengaruh kepada kelincahan.

\section{KESIMPULAN DAN SARAN \\ Kesimpulan}

Hasil temuan pada studi ini adalah latihan ladder drills in out dan ladder drills ickey shuffle dapat meningkatkan kelincahan dan kecepatan pada siswa yang mengikuti ekstrakurikuler futsal SMA Negeri 1 Krian. Manfaat yang dirasakan adalah meningkatknya klincahan dan kecepatan para siswa yang mengikuti ekstrakurikuler futsal.

\section{Saran}

Ada pun saran yang dapat dikembangkan untuk penelitian selanjutnya adalah untuk mengetahui efektivitas masing-masing latihan, kontrol kepada peserta penelitian lebih di awasi tidak melakukan aktivitas apa-apa selain data eksperimen, menghindari data-data yang tidak sesuai 
Faried Fatchurrahman, Andun Sudijandoko, dan Achmad Widodo

Perbandingan pengaruh latihan ladder drills in out dan ickey shuffle terhadap kecepatan dan kelincahan

dengan kenyataan kemampuan peserta itu sendiri. Selain itu, peneliti selanjutnya dapat mengembangkan penelitian dapat berupa penambahan beban latihan, penambahan variasi latihan ladder drill, atau menerapkan pada variabel terikat selain kecepatan dan kelincahan.

\section{DAFTAR PUSTAKA}

Anderson, J. (2019). Agility Ladder Drills. Retrieved May 25, 2019, from https://www.jenreviews.com/agility-ladder-drills/\#more-23855

Bompa, T. O., \& Haff, G. G. (2009). Theory and Methodology of Training. New York: Human Kinetics.

Chandrakumar, N., \& Ramesh, C. (2015). Effect of ladder drill and SAQ training on speed and agility among sports club badminton players. International Journal of Applied Research, 1(12), 527-529.

Chu, D. A., \& Myer, G. D. (2013). Dynamic Strength and Explosive Power. New York: Human Kinetics.

Fantiro, F. A. (2018). Perbedaan pengaruh latihan ladder drill speed run dan ladder drill crossover terhadap peningkatan kelincahan (agility) siswa Sekolah Dasar Moh. Hatta Kota Malang. Journal Power of Sports, 1(2), 14-22.

Mathisen, G. E. (2014). Effect of High-Speed and Plyometric Training for 13-Year-Old Male Soccer Players on Acceleration and Agility Performance. LASE Journal of Sport Science, 5(2), 1-12. https://doi.org/10.1515/ljss-2016-0027

McGinnis, P. M. (2013). Biomechanics of Sport and Exercise (Third Edition). Human Kinetics. Retrieved from https://books.google.co.id/books?hl=id\&lr=\&id=awmprqGqFo4C\&oi $=$ fnd \&pg =PP2\&dq=Biomechanics + of + Sport+and + Exercise Third+Edition\&ots $=0 \mathrm{xh} X$ Ald1 $\mathrm{Jb} \& \mathrm{sig}=9 \mathrm{y} 6 \mathrm{u} 4 \mathrm{DeQYqp} 4 \mathrm{ONXyd} 1 \log \times 2$ oWUc\&redir_esc $=\mathrm{y} \# \mathrm{v}=$ onepage\& $\mathrm{q}=$ Biomechanics of Sport and Exercise-Third Edition\&

Mylsidayu, A., \& Kurniawan, E. (2015). IImu Kepelatihan Dasar. Bandung: Alfabeta.

Pramukti, T., \& Junaidi, S. (2015). Pengaruh Latihan Ladder Drill dan Latihan ABC Run terhadap Peningkatan Kecepatan Pemanjatan Jalur Speed Atlet Panjat Tebing FPTI Kota Magelang. Journal of Sport Sciences and Fitness, 4(1), 40-43. Retrieved from https://journal.unnes.ac.id/sju/index.php/jssf/article/view/6274 
Puriana, R. H. (2017). Pengaruh Pelatihan Ladder Drill Hop Scotch Pattern terhadap Kelincahan pada Mahasiswa UKM Futsal Universitas PGRI Adi Buana Surabaya. Jurnal Buana Pendidikan, 1(1), 1-10.

Purnomo, R. H. (2018). Hubungan Kecepatan, Kelincahan dan Kelentukan dengan Kemampuan Menggiring Bola Dalam Permainan Futsal Pada Siswa Ekstrakulikuler Di Smp Negeri 3 Kota Kediri Tahun Ajaran 2017/2018. Universitas Nusantara PGRI Kediri.

Rajendran, K. (2016). Effect of Ladder Training on Agility among College level Football Players. International Journal of Recent Research and Applied Studies, 3(4), 99-101.

Rinaldi, R., Jumain, J., \& Marhadi, M. (2019). Pengaruh Latihan Ladder Drill 2 In Lateral dan Pull Up terhadap Power Otot Lengan pada Atlet Panjat Tebing Mapatala Universitas Tadulako. Tadulako Journal Sport Sciences And Physical Education, 6(1), 1-6. https://doi.org/10.22487/POR.V6l1.11081

Sethu, S. (2014). Comparison of Plyometric Training and Ladder Training on Sprinting Speed, Vertical Explosive Power and Agility. International Journal of Recent Research and Applied Studies, 1(1), 59-63. Retrieved from http://ijrras.com/comparison-of-plyometrictraining-and-ladder-training-on-sprinting-speed-vertical-explosivepower-and-agility/

Tefu, J. S. (2019). Pengaruh Latihan Ladder drill: Ladder Speed Run dan In Out Drill Terhadap Peningkatan Kecepatan dan Kelincahan. Jendela Olahraga, $4(1)$, 32-37. https://doi.org/10.26877/JO.V4l1.2986

Yudasakti, O. T. (2017). Pengaruh Latihan Plyometric dan Ladder Drill Terhadap Peningkatan Power Otot Tungkai, Kecepatan dan Kelincahan. Universitas Negeri Surabaya. 